\title{
Influence of the method of implementing the forced air flow through the cooling system on the temperature of the coolant in heavy-duty engines
}

The article discusses the problem how forced air flow is implemented through the cooling module of heavy-duty engines. The kinematic connection between the coolant pump and the crankshaft of the engine, results in the fact that the pump performance often does not correspond to the engine demand at its part load. In conjunction with the fan drive method, the temperature of the coolant may be too low or too high for part load. The study was carried out in order to calculate the parameters of the cooling system in heavy-duty engines for maximum power and maximum torque, taking into account a mechanical fan drive, a hydraulic fan drive and an electric fan drive.

Key words: heavy-duty engine, cooling system, heat transfer, coolant pump, fan

\section{Introduction}

The performance of a coolant pump results from the kinematic connection with the crankshaft and, in most cases, does not correspond to the current engine demand for the parameters of the cooling system. According to [1], a coolant pump generates a flow that far exceeds the engine demand, even up to $95 \%$ of operating time. This is due to the fact that the components of the cooling system must be chosen in such a way that with high ambient temperature the conditions are met for the maximum load of the engine. On the other hand, the engine in the vehicle often works with low loads and at idle speed, especially when operating in the traffic [7]. Then, the loss of cooling heat in the thermal balance is much higher than during nominal load of the engine. As a result, the overall efficiency of the engine differs from the nominal one, so fuel consumption is increased, as well as the emission of harmful exhaust components $[2,4,5,9]$.

In order to improve the efficiency of converting energy included in the fuel, higher and higher temperatures of cooling liquid are used $[4,7,9]$. This practice aims at increasing the temperature of the engine work cycle by reducing the heat losses from the combustion chamber to the environment. To keep in the cooling system of higher and higher temperatures one needs to use higher and higher values of pressure.

Another way to optimize the engine's performance is to use two thermostats in the cooling circuit to provide a higher temperature of the liquid in cylinders and lower temperature in cylinder head $[3,13]$.

There is currently extensive research carried out into the use of coolant pumps driven by an electric motor and into control of thermostat opening using an electromagnetic valve $[1-3,10]$. The electric drive of the pump eliminates the connection between the pump efficiency and the rotation speed of the engine so as to control the coolant flow depending on the instantaneous load on the engine. Besides that, immediately after the cold start of the engine, the pump may not be switched on until the coolant in the engine reaches the optimum temperature. This solution has already been used in VW's series produced engine (1.5 TSI evo).
In order to approximate the operating conditions of engines to adiabatic, the study is also being carried out concerning the use of ceramic coating on cylinder liners [6].

\section{Heavy-duty engines}

Heavy-duty compression ignition engines operate at a much lower rotational speed than in passenger vehicles, usually up to $2500 \mathrm{rpm}$. An example of an external speed characteristics of a heavy-duty engine is shown in Fig. 1.

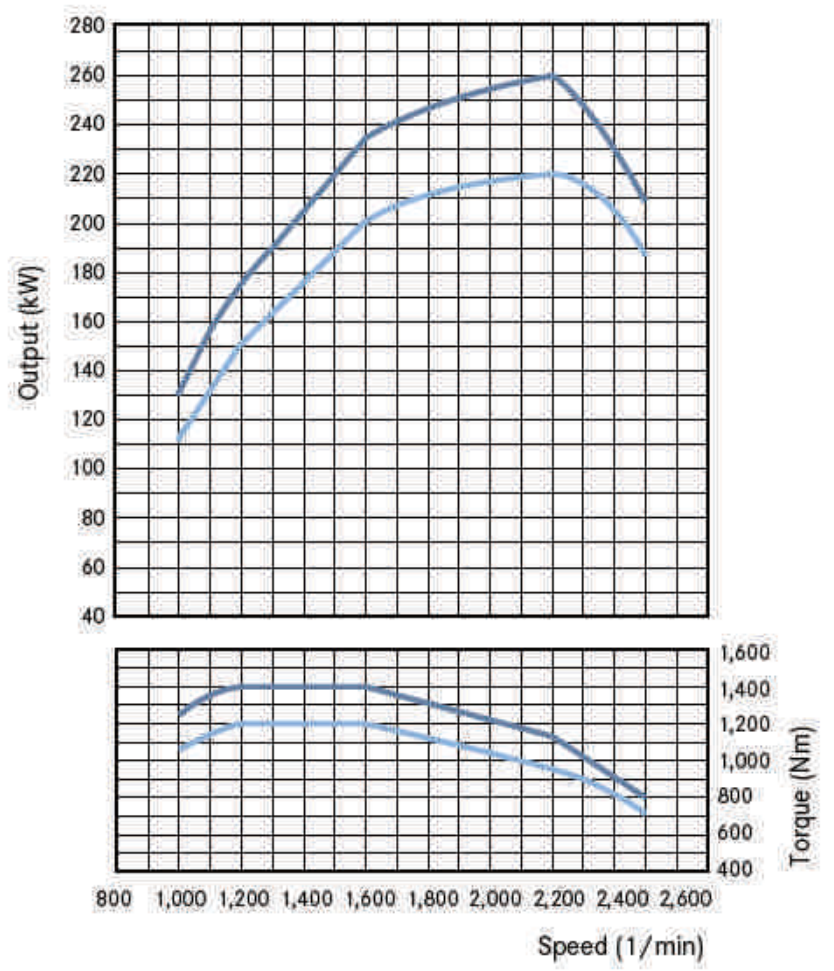

Fig. 1. External speed characteristics of a heavy-duty engine [14]

At the same time, they are more likely to work in stable heat conditions, as vehicles equipped with such engines cover long distances. Therefore, the kinematic connection between the crankshaft and the coolant pump is less unfavorable than that in a passenger vehicles. This does not mean, however, that the cooling parameters are optimal at each engine operating point. Apart from the appropriately 
selected characteristics of a coolant pump, it is also important to implement forced cooling air flow through the cooling module. In trucks, the fan is most often driven directly from the crankshaft or through a gear (eg. a fan mounted on a coolant pump). The alternative solution may be a hydraulic fan drive, commonly used in buses and special vehicles. Another solution increasingly used in city buses is the replacement of systems with one, hydraulically driven fan, with systems consisting of several fans with electric motors of considerably smaller diameters [8].

The variety of vehicles with heavy-duty engines results in the fact that mentioned above ways of the forced air flow through the cooling module cannot be used interchangeably. However, for the purpose of analyzing the influence of the fan drive method on the cooling parameters in the various operating parameters of the engine, the calculation of a cooling module was performed, taking into account all three ways of fan drive.

\section{Engines characteristics}

The engines meeting the EURO VI norms were selected for the analysis. These are six cylinder engines in a straight configuration, turbocharged, as well as EGR cooling system. They are equipped with a direct fuel injection system based on the Common Rail system and an extensive exhaust aftertreatment system consisting of an oxidation catalytic converter, a diesel particular filter and a reduction catalytic converter with AdBlue system. Engines 1 and 2 have the same maximum power and maximum engine torque, while the engine 3 comes from the same series as the engine 2, however, it has higher values of maximum power and of torque. The basic data of the engines are given in Table 1.

Table 1. Engines data [11, 12]

\begin{tabular}{|l|c|c|c|c|}
\hline Parameter & Unit & Engine 1 & Engine 2 & Engine 3 \\
\hline Rated power & $\mathrm{kW}$ & 224 & 220 & 260 \\
\hline At speed & $\mathrm{rpm}$ & 2100 & 2200 & 2200 \\
\hline Max torque & $\mathrm{Nm}$ & 1200 & 1200 & 1400 \\
\hline At speed & $\mathrm{rpm}$ & $1100-1700$ & $1200-1600$ & $1200-1600$ \\
\hline $\begin{array}{l}\text { Fuel Con- } \\
\text { sumption at } \\
\text { Rated Power }\end{array}$ & $\mathrm{g} / \mathrm{kWh}$ & 210 & 204 & 209 \\
\hline
\end{tabular}

\section{Calculations of the cooling system}

\subsection{Characteristics of the cooling system}

The cooling module in vehicles containing heavy-duty engines consists of a radiator, a charge air cooler, a condenser of air-conditioning system and a fan or fans. If the fan drive is hydraulic, the cooling module also includes the oil cooler of the fan drive system. In addition, the cooling module can include an air cooler of the pneumatic system. As the analysis concerns the engine, the condenser and the pneumatic air cooler were not included in the calculation. In all studied cases of the fan drive the same heat exchangers with the same core systems and dimensions were used as shown in Table 2 . The cooling system cover with a $60 \%$ clearance was also taken into consideration as it is an element on the path of air flow causing minor head loss.
Table 2. Heat exchangers dimensions

\begin{tabular}{|l|c|c|}
\hline \multicolumn{3}{|c|}{ Radiator core } \\
\hline height & $\mathrm{mm}$ & 900 \\
\hline width & $\mathrm{mm}$ & 700 \\
\hline depth & $\mathrm{mm}$ & 52 \\
\hline \multicolumn{3}{|c|}{ Charge air cooler core } \\
\hline height & $\mathrm{mm}$ & 650 \\
\hline width & $\mathrm{mm}$ & 600 \\
\hline depth & $\mathrm{mm}$ & 68 \\
\hline
\end{tabular}

Due to the range of data provided by heavy-duty engine manufacturers, the calculations were done for the parameters corresponding to the maximum engine power and the maximum torque. The cooling parameters that must be met for individual engines are shown in Table 3.

Table 3. Selected engine data at ambient temperature of $45^{\circ} \mathrm{C}[11,12]$

\begin{tabular}{|c|c|c|c|c|c|c|c|}
\hline \multirow[t]{2}{*}{ Parameter } & \multirow[t]{2}{*}{ Unit } & \multicolumn{2}{|c|}{ Engine 1} & \multicolumn{2}{|c|}{ Engine 2} & \multicolumn{2}{|c|}{ Engine 3} \\
\hline & & $\begin{array}{c}\mathrm{Ne} \\
\max \end{array}$ & $\begin{array}{l}\text { Mo } \\
\max \end{array}$ & $\begin{array}{l}\mathrm{Ne} \\
\max \end{array}$ & $\begin{array}{l}\text { Mo } \\
\max \end{array}$ & $\begin{array}{l}\mathrm{Ne} \\
\max \end{array}$ & $\begin{array}{l}\text { Mo } \\
\max \end{array}$ \\
\hline $\begin{array}{l}\text { Heat rejection to } \\
\text { coolant }\end{array}$ & $\mathrm{kW}$ & 133 & 102 & 152 & 105 & 167 & 122 \\
\hline Coolant flow & $1 / \mathrm{min}$ & 147 & 92 & 306 & 195 & 366 & 231 \\
\hline Coolant temp. max & ${ }^{\circ} \mathrm{C}$ & 107 & 107 & 105 & 105 & 105 & 105 \\
\hline $\begin{array}{l}\text { Temp. after turbo- } \\
\text { charger }\end{array}$ & ${ }^{\circ} \mathrm{C}$ & 172 & 191 & 195 & 186 & 215 & 210 \\
\hline $\begin{array}{l}\text { Charge air temp. } \\
\text { before engine }\end{array}$ & ${ }^{\circ} \mathrm{C}$ & 66 & 66 & 61 & 55 & 62 & 56 \\
\hline Charge air flow & $\mathrm{kg} / \mathrm{h}$ & 948 & 678 & 954 & 655 & 1098 & 792 \\
\hline
\end{tabular}

The work of the cooling module is affected by other elements of engine compartment, whose impact is difficult to predict at the design stage. Therefore, an additional safety factor should be taken into consideration. It has been assumed that the amount of heat rejection to coolant will be $10 \%$ higher than stated by the engine manufacturers.

Taking into account the climatic conditions prevailing in Europe, an ambient temperature of $45^{\circ} \mathrm{C}$ was adopted for the calculations for which the acceptable value of the charge air temperature was increased by $20 \mathrm{~K}$ respectively.

Calculations were made in the GT-SUITE computational package, using the characteristics of BSPL core heat exchangers.

\subsection{Fan drive from crankshaft}

In the first case, the simplest solution was considered, namely, the fan drive directly from the engine. As a result, the cooling module will include a radiator, a charge air cooler and a 9 - blade sucker fan with $680 \mathrm{~mm}$ diameter. Both the installation of the fan, on a crankshaft (ratio 1:1) and on the coolant pump (ratio: 1:1.1 and 1:1.2), were considered, as well as slipping on the clutch. Figure 2 shows the calculation model 3D of a cooling module, Figure 3 the calculation model 1D, while tables 4,5 and 6 show the results of the gear ratio between the engine and the fan respectively $1: 1 ; 1: 1.1 ; 1 ; 1.2$.

The kinematic connection of the fan with the engine is the cheapest option and is best suited for engines mounted on the front of the vehicle. However, very often it causes significant differences in coolant temperature values for maximum power and maximum torque. This is due to the amount of heat that must be transferred from the engine to the cooling system at maximum power and maximum torque and from the characteristics of the coolant pump and 
Influence of the method of implementing the forced air flow through the cooling system..

the fan. This prevents optimal selection of engine cooling parameters in various operating conditions and may result in over-sizing of the cooling module, especially if it is not possible to apply different ratios between engine speed and fan speed. On the other hand, the higher the fan speed, the greater the heat loss of the engine on its drive.

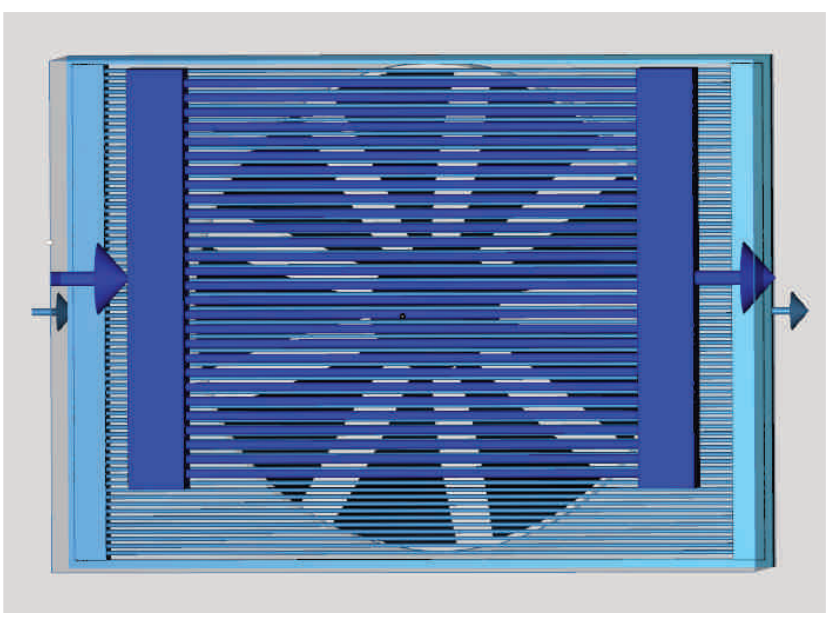

Fig. 2. Calculation model 3D of cooling module

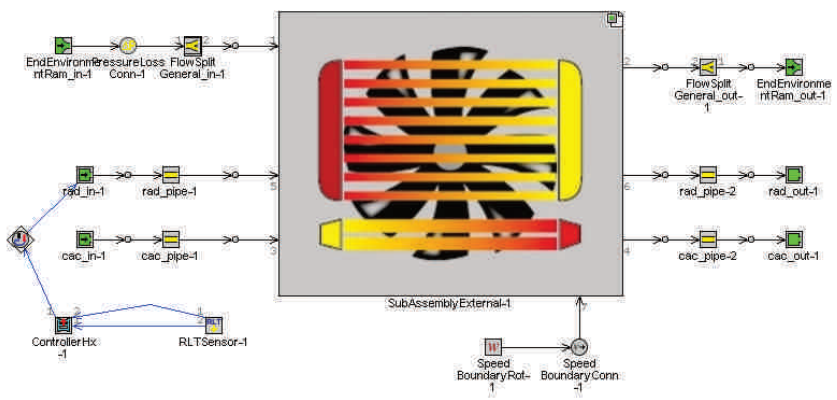

Fig. 3. Calculation model 1D of cooling module

Table 4. Calculation results, fan speed ratio 1:1

\begin{tabular}{|l|c|c|c|c|c|c|c|}
\hline Parameter & \multirow{2}{*}{ Unit } & \multicolumn{2}{|c|}{ Engine 1 } & \multicolumn{2}{c|}{ Engine 2 } & \multicolumn{2}{c|}{ Engine 3 } \\
\cline { 3 - 8 } & & $\begin{array}{c}\mathrm{Ne} \\
\mathrm{max}\end{array}$ & $\begin{array}{c}\mathrm{Mo} \\
\mathrm{max}\end{array}$ & $\begin{array}{c}\mathrm{Ne} \\
\mathrm{max}\end{array}$ & $\begin{array}{c}\text { Mo } \\
\mathrm{max}\end{array}$ & $\begin{array}{c}\mathrm{Ne} \\
\max \end{array}$ & $\begin{array}{c}\text { Mo } \\
\mathrm{max}\end{array}$ \\
\hline $\begin{array}{l}\text { Heat rejection to } \\
\text { coolant }\end{array}$ & $\mathrm{kW}$ & 146.3 & 112.9 & 167.2 & 116.7 & 183.7 & 135.2 \\
\hline $\begin{array}{l}\text { Coolant temp. } \\
\text { inlet engine }\end{array}$ & ${ }^{\circ} \mathrm{C}$ & 96.2 & 106.5 & 96.1 & 97.5 & 102.1 & 107.8 \\
\hline $\begin{array}{l}\text { Charge air temp. } \\
\text { inlet engine }\end{array}$ & ${ }^{\circ} \mathrm{C}$ & 50.4 & 50.5 & 51.2 & 49.3 & 54.6 & 53.1 \\
\hline Fan speed & $\mathrm{rpm}$ & 1950 & 1240 & 2050 & 1330 & 2050 & 1330 \\
\hline Cooling air flow & $\mathrm{kg} / \mathrm{s}$ & 5.19 & 3.05 & 5.41 & 3.34 & 5.32 & 3.23 \\
\hline Fan power & $\mathrm{kW}$ & 9.1 & 2.3 & 10.5 & 2.9 & 10.3 & 2.8 \\
\hline
\end{tabular}

Table 5. Calculation results, fan speed ratio 1:1.1

\begin{tabular}{|l|c|c|c|c|c|c|c|}
\hline Parameter & \multirow{2}{*}{ Unit } & \multicolumn{2}{|c|}{ Engine 1 } & \multicolumn{2}{c|}{ Engine 2 } & \multicolumn{2}{c|}{ Engine 3 } \\
\cline { 3 - 8 } & & $\begin{array}{c}\mathrm{Ne} \\
\max \end{array}$ & $\begin{array}{c}\mathrm{Mo} \\
\max \end{array}$ & $\begin{array}{c}\mathrm{Ne} \\
\max \end{array}$ & $\begin{array}{c}\text { Mo } \\
\max \end{array}$ & $\begin{array}{c}\mathrm{Ne} \\
\max \end{array}$ & $\begin{array}{c}\text { Mo } \\
\max \end{array}$ \\
\hline $\begin{array}{l}\text { Heat rejection to } \\
\text { coolant }\end{array}$ & $\mathrm{kW}$ & 146.3 & 112.6 & 167.2 & 116.3 & 183.7 & 134.8 \\
\hline $\begin{array}{l}\text { Coolant temp. } \\
\text { inlet engine }\end{array}$ & ${ }^{\circ} \mathrm{C}$ & 92.9 & 101.9 & 92.6 & 93.2 & 97.9 & 102.3 \\
\hline $\begin{array}{l}\text { Charge air temp. } \\
\text { inlet engine }\end{array}$ & ${ }^{\circ} \mathrm{C}$ & 49.9 & 49.7 & 50.6 & 48.7 & 53.7 & 51.9 \\
\hline Fan speed & $\mathrm{rpm}$ & 2150 & 1360 & 2250 & 1460 & 2250 & 1460 \\
\hline Cooling air flow & $\mathrm{kg} / \mathrm{s}$ & 5.81 & 3.44 & 6.03 & 3.76 & 5.94 & 3.66 \\
\hline Fan power & $\mathrm{kW}$ & 12.4 & 3.0 & 14.1 & 3.8 & 13.9 & 3.7 \\
\hline
\end{tabular}

Table 6. Calculation results, fan speed ratio 1:1.2

\begin{tabular}{|l|c|c|c|c|c|c|c|}
\hline Parameter & \multirow{2}{*}{ Unit } & \multicolumn{2}{|c|}{ Engine 1 } & \multicolumn{2}{c|}{ Engine 2 } & \multicolumn{2}{c|}{ Engine 3 } \\
\cline { 3 - 8 } & & $\begin{array}{c}\mathrm{Ne} \\
\max \end{array}$ & $\begin{array}{c}\mathrm{Mo} \\
\max \end{array}$ & $\begin{array}{c}\mathrm{Ne} \\
\max \end{array}$ & $\begin{array}{c}\text { Mo } \\
\max \end{array}$ & $\begin{array}{c}\mathrm{Ne} \\
\max \end{array}$ & $\begin{array}{c}\text { Mo } \\
\max \end{array}$ \\
\hline $\begin{array}{l}\text { Heat rejection } \\
\text { to coolant }\end{array}$ & $\mathrm{kW}$ & 146.3 & 112.5 & 167.2 & 116.0 & 183.7 & 134.6 \\
\hline $\begin{array}{l}\text { Coolant temp. } \\
\text { inlet engine }\end{array}$ & ${ }^{\circ} \mathrm{C}$ & 90.4 & 98.3 & 89.7 & 89.5 & 94.5 & 97.6 \\
\hline $\begin{array}{l}\text { Charge air } \\
\text { temp. inlet } \\
\text { engine }\end{array}$ & ${ }^{\circ} \mathrm{C}$ & 49.5 & 49.0 & 50.1 & 48.2 & 53.0 & 51.0 \\
\hline Fan speed & $\mathrm{rpm}$ & 2340 & 1480 & 2455 & 1600 & 2455 & 1600 \\
\hline $\begin{array}{l}\text { Cooling air } \\
\text { flow }\end{array}$ & $\mathrm{kg} / \mathrm{s}$ & 6.39 & 3.83 & 6.65 & 4.21 & 6.56 & 4.11 \\
\hline Fan power & $\mathrm{kW}$ & 15.9 & 4.0 & 18.5 & 5.0 & 18.3 & 4.9 \\
\hline
\end{tabular}

\subsection{Fan drive with hydraulic system}

The use of a hydraulic fan drive requires the expansion of the cooling module with a hydraulic pump and a hydraulic motor, as well as an oil tank and an oil cooler. This solution is much more expensive than the fan drive from the engine, but it allows the fan speed to be independent from the engine speed and the location of the cooling module from the engine mounting location.

It was assumed to use an external gear motor and two types of pumps: an external gear pump or axial piston pump. The type of pump was selected to provide optimum cooling parameters for both maximum engine power and maximum torque. The use of an axial piston pump results in the decrease of heat rejection by around $50 \%$ which is generated by the oil to the cooling module, thus reducing the oil cooler. Figure 4 shows the cooling module calculation model 3D, Figure 5 the calculation model 1D, and Table 7 shows the calculation results.

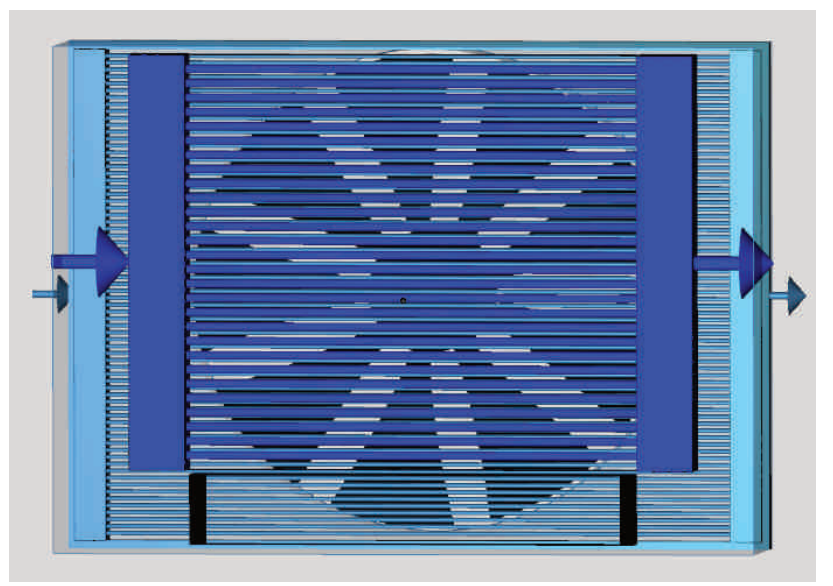

Fig. 4. Calculation model 3D of cooling module

The hydraulic fan drive allows for better adjustment of fan speed at various engine rotation speeds. However, the presence of certain types of hydraulic motors and hydraulic pumps results in the fact that the fan speed when running the engine with maximum torque will not always be optimal. During calculations, such a selection of fan operating parameters was assumed, that for maximum engine power the coolant temperature would be $3 \mathrm{~K}$ lower than the maximum temperature permitted by the engine manufacturer. This represents an additional safety factor in case of, for example, a greater major head loss in the coolant flow due to the greater distance between the engine and the radiator. 
For engines 1 and 3, the coolant temperature during operation of the engine with a maximum torque is about $1-2 \mathrm{~K}$ smaller, and for the engine 2 it is greater by about $1.5 \mathrm{~K}$. Keeping the coolant temperature close to maximum allowable values improves the efficiency of conversion of energy contained in the fuel.

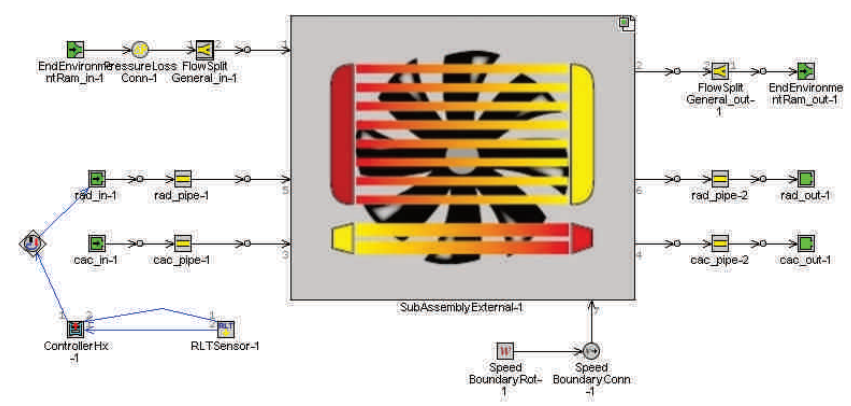

Fig. 5. Calculation model 1D of cooling module

Table 7. Calculation results, hydraulic fan drive

\begin{tabular}{|l|c|c|c|c|c|c|c|}
\hline Parameter & Unit & \multicolumn{2}{|c|}{ Engine 1 } & \multicolumn{2}{c|}{ Engine 2 } & \multicolumn{2}{c|}{ Engine 3 } \\
\cline { 3 - 8 } & & $\begin{array}{c}\mathrm{Ne} \\
\max \end{array}$ & $\begin{array}{c}\mathrm{Mo} \\
\mathrm{max}\end{array}$ & $\begin{array}{c}\mathrm{Ne} \\
\max \end{array}$ & $\begin{array}{c}\text { Mo } \\
\max \end{array}$ & $\begin{array}{c}\mathrm{Ne} \\
\max \end{array}$ & $\begin{array}{c}\text { Mo } \\
\max \end{array}$ \\
\hline $\begin{array}{l}\text { Heat rejection } \\
\text { to coolant }\end{array}$ & $\mathrm{kW}$ & 146.4 & 112.6 & 167.2 & 116.7 & 183.7 & 134.7 \\
\hline $\begin{array}{l}\text { Coolant temp. } \\
\text { inlet engine }\end{array}$ & ${ }^{\circ} \mathrm{C}$ & 103.9 & 102.3 & 102.1 & 103.6 & 102 & 100.9 \\
\hline $\begin{array}{l}\text { Charge air } \\
\text { temp. inlet } \\
\text { engine }\end{array}$ & ${ }^{\circ} \mathrm{C}$ & 51.4 & 49.3 & 52.0 & 49.9 & 54.4 & 51.4 \\
\hline Fan speed & $\mathrm{rpm}$ & 1700 & 1430 & 1850 & 1240 & 2100 & 1540 \\
\hline $\begin{array}{l}\text { Cooling air } \\
\text { flow }\end{array}$ & $\mathrm{kg} / \mathrm{s}$ & 4.37 & 3.64 & 4.76 & 3.02 & 5.46 & 3.9 \\
\hline Fan power & $\mathrm{kW}$ & 5.9 & 3.5 & 7.6 & 2.3 & 11.1 & 4.4 \\
\hline $\begin{array}{l}\text { Heat rejection } \\
\text { to oil }\end{array}$ & $\mathrm{kW}$ & 9.0 & 9.0 & 6.3 & 6.3 & 5.0 & 5.0 \\
\hline
\end{tabular}

\subsection{Fan drive with electric motor}

A 24 volt electrical installation on vehicles with heavyduty engines excludes the use of a single large electric motor driven fan. Instead of that, several fans with a much smaller diameter are used, which operate at high rotation speed. These fans produce significantly lower pressure values. In addition, the control system is required so that, at part load and low ambient temperature, the fans would not working at maximum speed.

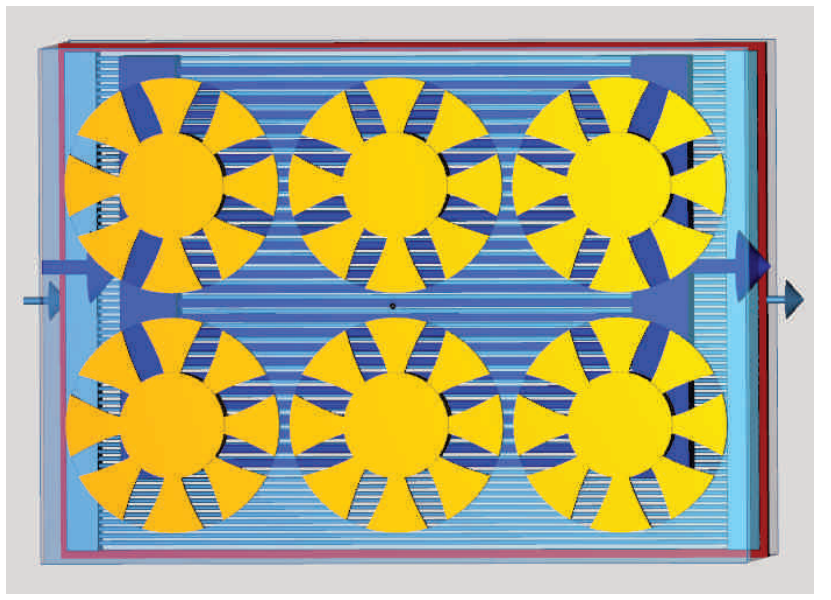

Fig. 6. Calculation model 3D of cooling module
For the calculation, six blower fans were used for these applications, with a diameter of $305 \mathrm{~mm}$ with brushless motors. The number of fans is the result of the amount of available space for their installation, namely, the frontal area of the cooling module. Figure 6 shows the calculation $3 \mathrm{D}$ model of the cooling module with electric motors, Figure 7 the cooling module calculation model 1D, and Table 8 shows the calculation results.

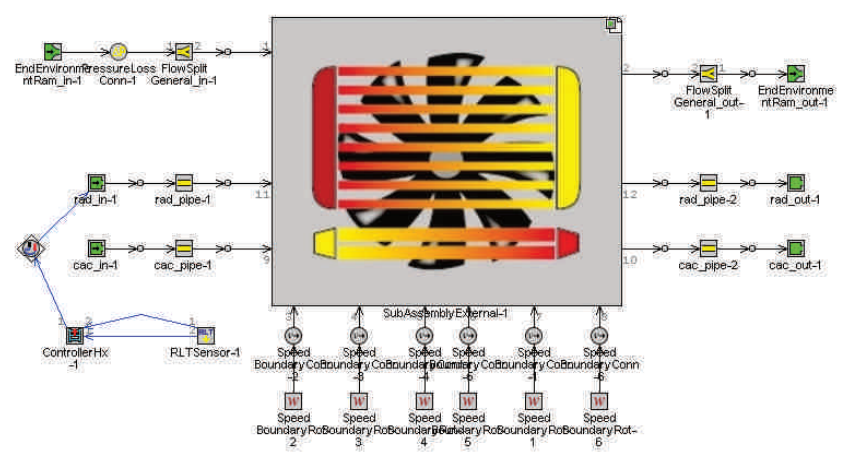

Fig. 7. Calculation model 1D of cooling module

The use of six $305 \mathrm{~mm}$ diameter fans with electric motors instead of one with diameter $680 \mathrm{~mm}$ with a mechanical drive, or a hydraulic drive, does not provide the right temperature of the coolant for engines 2 and 3 in operation with maximum power. Electric driven fans produce much less pressure, so they work better in side by side systems than in a sandwich one. The module with parallel arrangement of heat exchangers is usually larger, so it takes up more space in the vehicle. Electric driven fans running at maximum speed generate a large noise. Electric fan drive is a heavy load for the electrical installation of the engine.

Table 8. Calculation results, 6 fans with electric motor

\begin{tabular}{|l|c|c|c|c|c|c|c|}
\hline Parameter & Unit & \multicolumn{2}{|c|}{ Engine 1 } & \multicolumn{2}{c|}{ Engine 2 } & \multicolumn{2}{c|}{ Engine 3 } \\
\cline { 3 - 8 } & & $\begin{array}{c}\mathrm{Ne} \\
\mathrm{max}\end{array}$ & $\begin{array}{c}\mathrm{Mo} \\
\mathrm{max}\end{array}$ & $\begin{array}{c}\mathrm{Ne} \\
\mathrm{max}\end{array}$ & $\begin{array}{c}\mathrm{Mo} \\
\mathrm{max}\end{array}$ & $\begin{array}{c}\mathrm{Ne} \\
\max \end{array}$ & $\begin{array}{c}\text { Mo } \\
\mathrm{max}\end{array}$ \\
\hline $\begin{array}{l}\text { Heat } \\
\text { rejection to } \\
\text { coolant }\end{array}$ & $\mathrm{kW}$ & 146.4 & $\begin{array}{c}112 . \\
6\end{array}$ & $\begin{array}{c}167 . \\
3\end{array}$ & $\begin{array}{c}116 . \\
9\end{array}$ & $\begin{array}{c}183 . \\
8\end{array}$ & $\begin{array}{c}134 . \\
6\end{array}$ \\
\hline $\begin{array}{l}\text { Coolant } \\
\text { temp. inlet } \\
\text { engine }\end{array}$ & ${ }^{\circ} \mathrm{C}$ & 105.2 & $\begin{array}{c}103 . \\
5\end{array}$ & $\begin{array}{c}108 . \\
4\end{array}$ & $\begin{array}{c}103 . \\
3\end{array}$ & $\begin{array}{c}115 . \\
6\end{array}$ & $\begin{array}{c}102 . \\
1\end{array}$ \\
\hline $\begin{array}{l}\text { Charge air } \\
\text { temp. inlet } \\
\text { engine }\end{array}$ & ${ }^{\circ} \mathrm{C}$ & 52.3 & 50.2 & 53.7 & 50.5 & 57.9 & 52.2 \\
\hline Fan speed & $\mathrm{rpm}$ & 4750 & 4000 & 4750 & 3600 & 4750 & 4400 \\
\hline $\begin{array}{l}\text { Cooling air } \\
\text { flow }\end{array}$ & $\mathrm{kg} / \mathrm{s}$ & 4.05 & 3.32 & 4.02 & 2.9 & 3.99 & 3.69 \\
\hline Fan power & $\mathrm{kW}$ & 4.5 & 3.8 & 4.5 & 3.3 & 4.5 & 4.1 \\
\hline
\end{tabular}

\section{Conclusions}

The reduction of heat losses from the combustion chamber results in improved overall efficiency of the engine which, in turn, leads to lower fuel consumption and decrease of harmful exhaust components. This is accomplished, among others, by increasing the coolant temperature or by selecting a pump whose characteristics enables to reach the optimum coolant flow within the maximum possible range of rotation speed of the engine. Engine cooling 
parameters are also influenced by non-engine cooling system components such as heat exchangers or fan characteristics.

Vehicles with heavy-duty engines use different fan drive methods, depending on the location of the engine in the vehicle. The mechanical fan drive is the simplest and cheapest solution, but it usually produces a significant difference in the coolant temperature between the maximum power and the maximum torque of the engine. This is due to the characteristics of the engine and the pump, but also to the resulting high difference in fan speed at the analyzed points of engine operation. The fan efficiency at low rotation speeds is considerably reduced. The alternative solu- tion is a hydraulic fan drive, which is commonly used when placing the engine at the rear of the vehicle. The hydraulic system is much more expensive and more complicated, because it consists of more components. However, it allows for such a the selection of components that the coolant temperature can have an optimum value concerning a wide range of engine rotation speed. In city buses, besides the hydraulic fan drive, electric fans are also used, due to the lower cost. This system is suitable for low power engines, also it generates more noise and is a heavy load for the electrical installation of the vehicle.

\section{Bibliography}

[1] ZHOU, B., LAN, X., XU, X., LIANG, X. Numerical model and control strategies for the advanced thermal management system of diesel engine. Applied Thermal Engineering. 2015, 82, 368-379.

[2] EID, S.M. Development and analysis of a variable position thermostat for smart cooling system of a light duty diesel vehicles and engine emissions assessment during NEDC. Applied Thermal Engineering. 2016, 99, 358-372.

[3] KNEBA, Z. Development trends of automotive engine cooling systems. Combustion Engines. 2013, 154(3), 291296.

[4] KRAKOWSKI, R. Wpływ podwyższonej temperatury płynu chłodzącego na zwiększenie ekonomiczności pracy tłokowego silnika spalinowego. Zeszyty naukowe Akademii Morskiej w Gdyni. 2011, 71.

[5] KRAKOWSKI, R. Model and experimental research of the pressure cooling system for the internal combustion engine. Journal of KONES Powertrain and Transport. 2014, 21(4).

[6] MITIANIEC, W. Assessment of total efficiency in adiabatic engines. Scientific Conference on Automotive Vehicles and
Combustion Engines. IOP Conf. Series: Materials Science and Engineering. 2016, 148, 012080.

[7] WORSZTYNOWICZ, B. Bilans cieplny silników spalinowych typu heavy-duty w aspekcie norm emisji. Silniki spalinowe i ekologia - opracowanie monograficzne. Wydawnictwo Politechniki Krakowskiej. Kraków 2014.

[8] WORSZTYNOWICZ, B. The influence of fuel type on the cooling system heat exchanger parameters in heavy - duty engines. Scientific Conference on Automotive Vehicles and Combustion Engines, IOP Conf. Series: Materials Science and Engineering. 2016, 148, 012080.

[9] WORSZTYNOWICZ, B., UHRYŃSKI, A. The analysis of heating process of catalytic converter using thermo-vision. Combustion Engines. 2015, 162(3), 41-51.

[10] CHEN, X., YU, X., LU, Y. et al. Study of different cooling structures on the thermal status of an internal combustion engine. Applied Thermal Engineering. 2017, 116, 419-432.

[11] Cummins - factory data.

[12] Mercedes-Benz - factory data.

[13] VW Self study programme 296.

[14] www.mercedes-benz.pl.
Barbara Worsztynowicz, DEng. - Faculty of Mechanical Engineering and Robotics at AGH University of Science and Technology.

e-mail: Worsztyn@agh.edu.pl

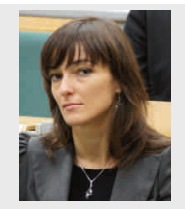

